\title{
Medicine, the arts and humanities
}

\author{
Brian Hurwitz
}

Medicine is the most humane of the sciences, the most scientific of the humanities.

Edmund Pellegrino $1979^{1}$

The humanities are reflective endeavours, which seek to retrieve, record and interpret the span of human experience. Originating in the Renaissance studia humanitatis, and influenced by the educational programme of the Greeks and Romans, which centred originally on grammar, rhetoric, history, poetry and ethics, the humanities, today, encompass many fields of enquiry: literature, drama, philosophy, theology, anthropology, and on some accounts, law. These disciplines value reason, explore emotion, focus on meaning and ambiguity and generally approach their subjects from multiple viewpoints. They also engage with aspects of human life clinicians meet daily, such as biography, motivation, the influences of character and personality on consequences and outcomes, human feelings and foibles, matters of evidence, and of causal inference.

Productive clinical encounters depend on diverse sorts of communications: spontaneous and staged, verbal and non-verbal, intimate and detached interchanges, observations and interpretations. To consult well, clinicians deploy what has been termed the 'instrument of human faculty, ${ }^{2}$ an amalgam of attitudes, responses and skills, which supports listening and looking, and enables facts, risks, emotions and values to be synthesised and interpreted. The notion of an instrument of human faculty which underpins the valences of clinical skill was first formulated in 1941 by the surgeon, Wilfred Trotter; he conceived it to be a compound of clinical attentiveness, intuition (inference from experience), an ability to handle living flesh sensitively and confidently ('mutton fist' and 'beefy mind' no use here), and genuine interest in both the person who is the patient, and the cause of the patient's complaint. ${ }^{3}$ While depending on the sciences and their emphases on measurement, hypothesis testing and falsifiability, clinicians also find it useful to draw on the arts and humanities, with their emphases on meaning and interpretation. ${ }^{4}$

William Osler believed a strong desire for medicines distinguishes humans from animals. ${ }^{5}$ Uniquely, humans are also characterised by the desire to create artefacts which aesthetically engage and move others. The arts are the practices, artefacts and faculties through which - consciously or subconsciously - we respond to such desires, ${ }^{6}$ and they thereby add to the thoughts and emotions of humankind. ${ }^{7}$ The arts play upon our senses and help order, illuminate and deepen experience. Their effects work through reflective and imaginative processes: 'You use a glass mirror to see your face: you use works of art to see your soul' wrote George Bernard Shaw in Back to Methuselah.

In addition to contemplating mental images seeing inwardly - the faculty of imagination deploys processes of visualisation and creativity essential to thinking diagnostically, scientifically and artistically. ${ }^{8-9}$ It is the imaginative faculty, with its capacities for 'forming images which go beyond reality, which turn reality into song' ${ }^{10}$ that enables us to envision the plights of others, to identify with, and feel empathy for, patients.

Educationally, the arts and humanities develop a range of skills and capacities: from observation, argument and analysis, to self-awareness, capabilities that are insufficiently nurtured by school science courses and conventional medical curricula. Caring for sick people frequently confronts nurses and doctors with intense questions about the meaning of life and exposes them to human tragedies and comic absurdities, sometimes simultaneously. The arts can tackle such issues with an immediacy and range of response often lacking in medicine. ${ }^{11-12}$

The term 'medical humanities' was first coined in 1976 by Australian surgeon, A R Moore, when introducing undergraduates to readings of literary works during a surgical attachment in Melbourne. ${ }^{13}$ The course successfully stimulated 'students to broaden the cultural breadth of their education in an enjoyable way.... and [in a way] relevant to their experience as medical students ${ }^{14}$ and Moore later added an appreciation of paintings component to the course. 'Medical humanities' now denotes a growing area of engagement and exchange between the humanities and medicine, ${ }^{15,16,17}$ covering:

- use of the arts in therapy and human comforting - painting, poetry, music and creative writing

- the arts as foci for meditative appreciation, decorative enjoyment and environmental improvement in an otherwise uninterestingsometimes bleak - health services environment ${ }^{18}$
Brian Hurwitz MD FRCGP FRCP, D'Oyly Carte Professor of Medicine and the Arts, King's College, London 
- the value of the arts in health promotion, as forms of artistic and communicative display which can embody welfare messages relevant to the health of the public

- the contribution of the arts and humanities to interdisciplinary research and teaching in health care.

A series of meetings in 2003 attests to the vitality of humanities, arts and medicine initiatives in the UK and USA. The theme of this year's annual meeting of the UK Faculty of Public Health Medicine was arts for health, ${ }^{19}$ and the Association for the Medical Humanities in the UK, which promotes education and research in the medical humanities, ${ }^{20}$ staged its first conference in Durham in July, drawing delegates from mainland Europe, the USA and the UK. The conference was opened by Sir Kenneth Calman, Vice Chancellor of Durham University, and one of the main instigators of interest in this field. The conference addressed the development of medical humanities as an area of practice and research, and as an arena for understanding and improving health care. In October 2003, New York University's Master Scholars Program and the Centre for Medical Humanities at University College, London, convened a two-day meeting in New York, which focused on medical humanities and the good doctor. ${ }^{21}$ Many health care organisations, including the Royal College of Physicians, ${ }^{22-23}$ are participating in these developments, which are bringing to the fore dynamic and diverse affinities between medicine, the arts and the humanities.

\section{References}

1 Pellegrino ED. Humanism and the physician. Knoxville: University of Tennessee Press 1979, 16-17.

2 Smith LH. Medicine as an art. In: Wyngaarden JB, Smith LH [eds]. Cecil textbook of medicine [18th edition]. Philadelphia: WB Saunders, 1988: 2.

3 Trotter W. Art and science in medicine. In: Trotter W (ed) The collected papers of Wilfred Trotter FRS. Oxford: OUP 1941, 85-101.

4 Warsop A. Art, science, and the existential focus of clinical medicine. Journal of Medical Ethics: Medical Humanities 2002;28:74-77.

5 Osler W. Teaching and thinking. In: Aequanimitas. 3rd ed. London: H K Lewis, 1939:125.

6 Marwick A. The arts in the West since 1945. Oxford: OUP 2002.

7 Madox Ford F. It was the Nightingale. London 1934, cited in: Saunders M, Stang R. Ford Madox Ford: Critical Essays. Manchester: Caranet Press. 2002, xii.

8 Miller AI. Imagery in scientific thought. Cambridge, Massachusetts: First MIT Press 1986.

9 Aziz J, Bruce V, Potter D, Rothschild E. Imagination and understanding: a report on the arts and humanities in relation to science and technology. London: Council for Science and Technology, 2001.

10 Bachelard G. L'Eau et les reves (1942) Quoted by Moran M. Metaphysical imagination. In: Weiner PP [ed] Dictionary of the history of ideas Vol 3. New York: Charles Scribner's Sons 1973, 208-23.

11 Calman $\mathrm{K}$ and Downie R. Why arts courses for medical curricula? Lancet 1996;34:1499-500.

12 Sweeney B. The place of the humanities in the education of a doctor. BJGP 1998;48:998-1102.

13 More A R. Medical humanities - a new medical adventure. NEJM 1976;295:1479-80.

14 Moore A R. Medical humanities: an aid to ethical discussions. J Med Ethics 1977;3:26-32.

15 Evans M, Greaves D. Exploring the medical humanities. BMJ 1999;
319:1216.

16 Evans M, Greaves D. Medical humanities. Journal of Medical Ethics: Medical Humanities 2000; 1:1-2.

17 Lewis W. Medical humanities. BMJ 2003;327(suppl)s65-6.

18 http://www.kingsfund.org.uk/Grants/Enhancing_The_Healing_ Environment.html (accessed June 2003)

19 http://www.fphm.org.uk/Events/ASM/ASM.shtml (accessed June 2003)

20 Evans HM, Greaves DA. 'Medical humanities' - what's in a name? Journal of Medical Ethics: Medical Humanities 2002;28:1-2.

21 http://www.pcps.ucl.ac.uk/cmh/conference_2003.html (accessed June 2003).

22 Kirklin D, Richardson R. (eds) Medical humanities. London: Royal College of Physicians 2001.

23 Kirklin D, Richardson R. (eds) The healing environment. London: Royal College of Physicians 2003. 